\title{
ALESSANDRO ANTONELLI AND THE BAROQUE PRE-EXISTENCE: THE PROJECT FOR THE NATIONAL PARLIAMENT IN TURIN.
}

\author{
F. Giusti
}

Scuola di Specializzazione, DIDA, Università degli Studi di Firenze. Firenze, Italia. francescabenedettagiusti@gmail.com

KEY WORDS: Alessandro Antonelli, National Parlament, Turin, 3D modeling, Digital History

\begin{abstract}
:
The contribution is focused on Alessandro Antonelli's project for the seat of the new italian parliament in Turin. The project, unrealized, began back in 1860, when the annexation to the Piedmont of Tuscany and the Emilia asked for the building in the capital of a decent seat for the National Parliament. It had to be situated on the area of the ex Carignano garden, behind the homonym building and the "antonellian" Collegio delle Provincie, in the heart of the city, that comes to be as representative place of the absolutist and dynastic power, through the phases of XVIIIth century of amplification and architectural-urbanism new configuration.

To deepen therefore the knowledge of Antonelli's project and to understand better the reasons that have brought to the choice to locate in Palazzo Carignano the Italian Parliament, is has been chosen to deepen the relationships between the building and the city, through a punctual iconografic and archivistic documentation that it has allowed to read the development of the building among XVIIth and XIXth century, also in relationship to the urban transformation, putting to comparison the various projects of the contest with the Baroque existence. Through the restitution of virtual images it has been possible to optimize the hypothesis, putting not only to fire the philosophy of the project, but above all Antonelli's way to measure himself with such an incisive existence in the city as the "guariniano" Palazzo Carignano and to bring back the linguistic choice to the amplest circle of the works that the architect realized in the city of Turin.
\end{abstract}




\section{Alessandro Antonelli's project}

Alessandro Antonelli's project, thought for the seat of the new Italian Parliament, dates back to the 1860, when the annexation of Tuscany and Emilia to Piemonte asked for the building in the capital of a suitable seat to the representative role of the National Parliament. Antonelli's commitment, already Kingdom of Sardinia's deputy and architecture's professor at Accademia Albertina in Turin ${ }^{1}$, cannot be achieved and it remains on the paper. Nevertheless the solution that he has adopted appears meaningful for the relationship that comes to establish with the urban palimpsest. The position of the new Parliament was in fact planned in the heart of the city on the area of the ex Carignano garden, behind the homonym building and the "antonelliano" Collegio delle Provincie, projected between 1843 and 1844 (demolished in the postwar period), in nearness to the stables of the same building. On the $26^{\text {th }}$ of July opens therefore a contest for the realization of the National Parliament's seat, to which follows, over the next months the presentation of the elaborate ones, including that of Alexander Antonelli ${ }^{2}$. The site, in proximity of Palazzo Reale and Palazzo Madama, is located in the heart of the city that comes to define itself as the representative place of the absolutist-dynastic power, already since the XVIIth century phases of amplification and architectural-urbanism reconfiguration. That, starting from the urban development of 1620, wanted from Carlo Emanuele I that enlarge the city in direction of the south, joining Piazza Castello with Porta Nuova throw the actual Piazza San Carlo (at that time was Piazza d'Armi) with the layout of the present via Roma ${ }^{3}$. This enlargement is continued in the last thirty years of the XVIIth century by Emanuele II (and from his regent wife Giovanna Battista of Savoia-Nemours) that addresses the urban expansion toward the river, marked by the layout of the today's via $\mathrm{Po}^{4}$. The amplification projects in the south and east part of the city are owed to Charles and then to Amedeo of Castellamente (took over his father in the position of ducal architect) that plan the project on criterions of architectural uniformity and urbanism ${ }^{5}$. Guarino Guarini also sticks to these criterions in the project of Palazzo Carignano, where "it infringes" from the repetitive rigor of the fronts and the weaving in tile of the facades, producing a game of concave and convex, sinuous solutions of the insides, with the atrium to form of oval that bends the façade in its central portion and a room of light, organized in a structure to double vault, inside the saloon of honor ${ }^{6}$. It's interesting to underline these formal aspects because they help to understand better the logic of the choices of second part of XIXth century - and in the specific Alessandro Antonelli's project. This project, even if it remains on the papers, owes in fact to be framed in the process of definition of the double façade of the building that underlines, from a side the recognition of the quality of Guarini's project from the XIXth century architectural culture and from the other the wish to engrave on the urban fabric with an image suitable to the new role of the Building.

Alessandro Antonelli's project for the seat of new National Parliament has colossal dimensions: the architect assembles two rooms in an only building to set to Palazzo Carignano, almost prolonging its thin perimeter to reach the alignment of via Carlo

\footnotetext{
${ }^{1}$ PORTOGHESI 1961 within the following one.

${ }^{3}$ COMOLI MANDRACCI 1983, p. 54

${ }^{4}$ ivi p. 58.

5 ivi p. 62.

${ }^{6}$ CERRI 1990, p 26.
}

2 The proclamation is published on Gazzetta Ufficiale of the Kingdom the $28^{\text {th }}$ of July 1860, and the projects must be deliver
Alberto. For this, Antonelli prolongs the old courtyard of two spans closing it with a building deeps fifty meters, where it assembles both the Chambers. The prospectus toward Piazza Carlo Alberto is characterized by a neoclassic language, emphasized by a double order of Corinthian columns, with a light discard emerged from the central score, constituted from an attic plan with statues and from an eardrum with an arrears crowning (it's important to notice the particular and meaningful assonance with the architectural parties of the base of Mole structure). At the ground floor it is situated a portico toward the plaza with an atrium to five spans that it transversally intercepts it, followed by a double portico toward the courtyard on which two monumental staircases are overlooking and that bring to the two Chambers. The first floor is entirely occupied in the center of the room by royal seats, in which the smaller classrooms of the Senate and the Elective Chamber are placed side by side, surround from antechambers, hallways, galleries of redemption and diversion, libraries. Room and classrooms form an only environment, illuminated by two orders of windows and divided by two floors galleries, where in the inside and above find place the galleries for the public ${ }^{7}$. With this project the plaza, magnified by the portico, it is not anymore on the same axle of symmetry (coaxial) of via Carlo Alberto, but it's on the contrary tangential. The street crosses it and tape it, and the monument is moved in its center, compromising its centrality in comparison to the perspective of the road. For this reason, Antonelli's project, that aroused great admiration, is discarded by the commission, because held in conflict with $t$ Alexander Mazzucchetti's project for Piazza Carlo Alberto (1842 - 1859), completed with the position of the Carlo Alberto's statue ${ }^{8}$. In this way the committee opted for the solution corresponding to that actual, realized on Domenico Ferri's project $(1863-1871)^{9}$.

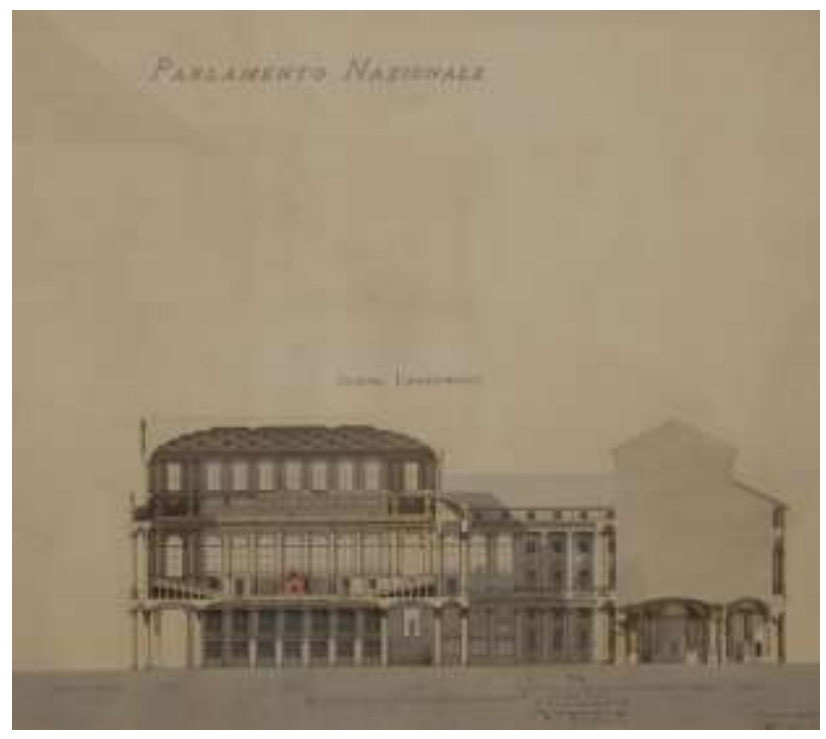

Figure 1. Alessandro Antonelli, National Parliament, section, 30th august of 1860, Porcheddu Archive, Polithecnic of Turin, Turin.

7 The description of Antonelli's project is published on "Il Diritto", and it is probably written from the same Antonelli, even if in the text he's named in third person (ASCT, Corrispondenza LL.PP., n, 282, c.23, f. 1).

${ }^{8}$ CERRI 1990, p. 119.

${ }^{9}$ Ivi, p. 120. 


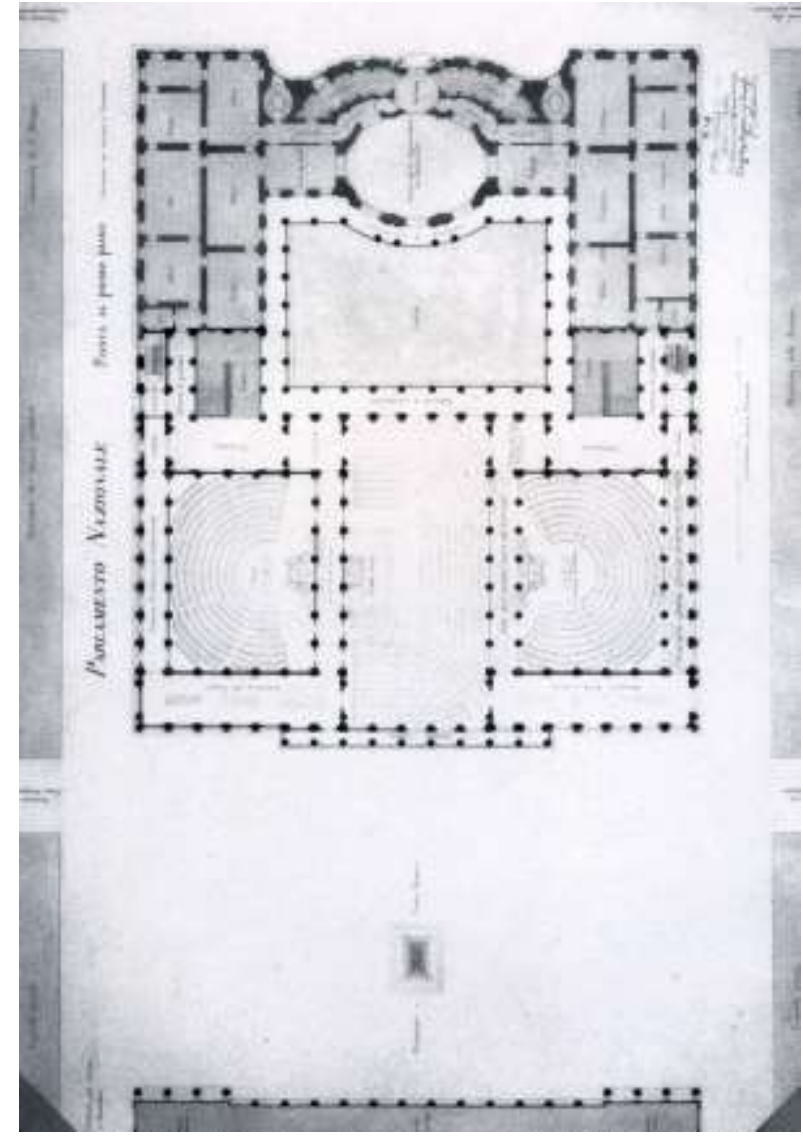

Figure 2. Alessandro Antonelli, National Parliament, first floor, 30th august of 1860, Porcheddu Archive, Polithecnic of Turin, Turin

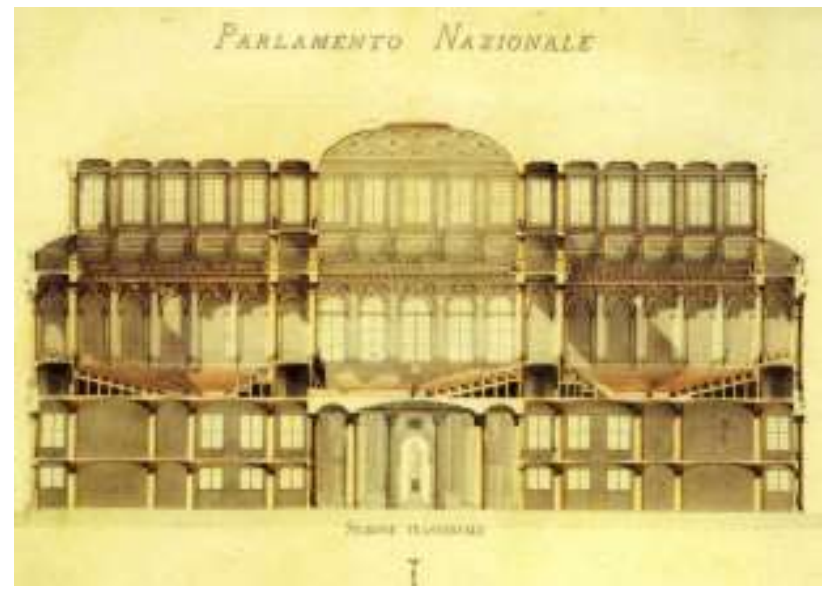

Figure 3. Alessandro Antonelli, National Parliament, elevation, 30th august of 1860, Porcheddu Archive, Polithecnic of Turin, Turin

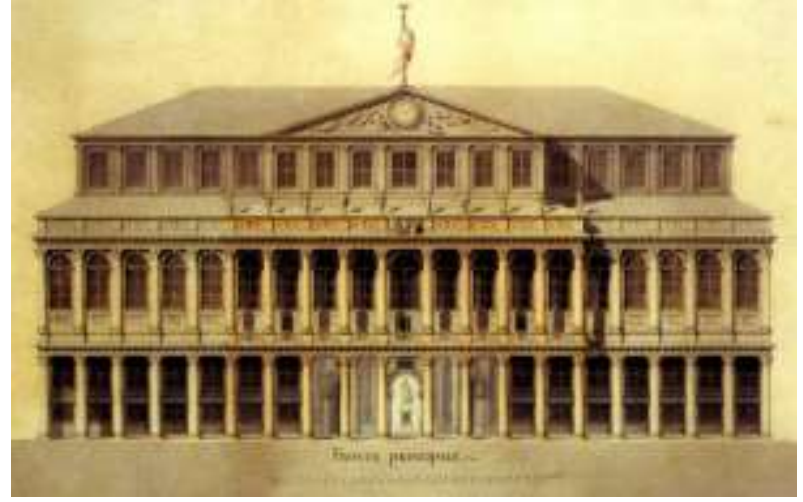

Figure 4. Alessandro Antonelli, National Parliament, trasversal section, 30th august of 1860, Porcheddu Archive, Polithecnic of Turin, Turin

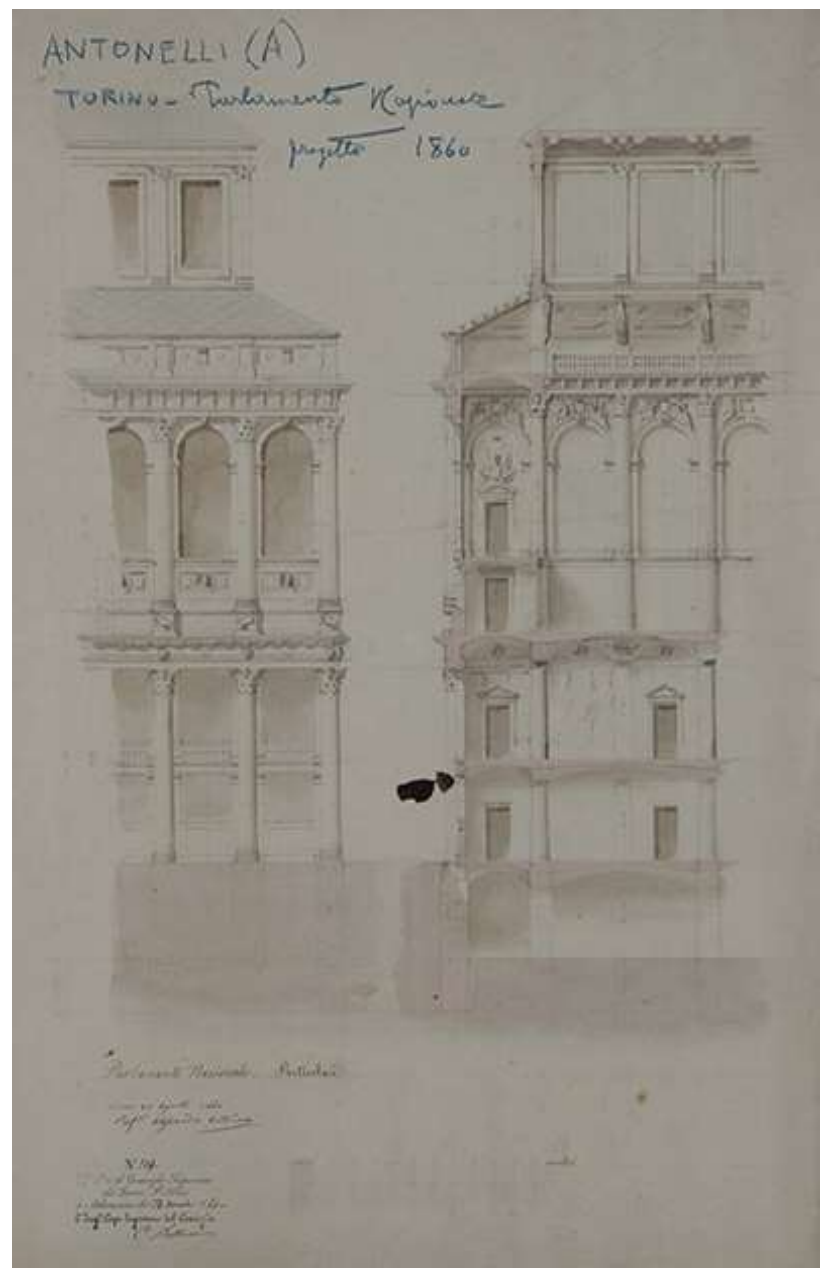

Figure 5. Alessandro Antonelli, National Parliament, particular, 30th august of 1860, GAM, Turin 


\section{The virtual restitution of the project}

From a first vision of the documents of file of the "antonellian" project and from the innumerable bibliographical sources that talk about Palazzo Carignano's project, it was decided to use the program Sketch-up ${ }^{10}$ to realize a virtual model with the objective to read the development of the building among XVIIth and XIXth century, also in relationship to the urban transformation, putting to comparison the various projects of the contest with the preexistence. The choice is due to the relative facility with which the program allows to realize curved forms and surfaces with more bending, such as Palazzo Carignano coverage and other parts of the model, in plan and in elevation. The models of the realized buildings have been three, besides the one of the urban context that represents the scenary of the complex, attested on Piazza Carignano and Piazza Carlo Alberto.

The first realized model has been that of Palazzo Carignano, followed from the model of Parliament's Provisional room realized in 1861 and lastly the model of Alessandro Antonelli's project, that how we have seen, it won't be winning of the contest, in how much held not conforming to the indication furnished by the commission that asked for coherence with the urban scene determined by the new plaza. Beside to analyze the role that the project would have assumed in the urban context we have chosen to also represent the buildings around the two plazas and some isolated neighboring. All the models have been realized without the original coloration since it has not been possible to retrieve the necessary information on the material consistences for every single building and for uniformity and coherence of informations with the original documents, a neutral form of representation has been chosen, going to furnish only formal notions, that focus the attention just on the linguistic and spatial choices of the Antonelli's idea. In order to retrace the same projectual procedure of the architect it has been decided to depart from the realization of the model of Palazzo Carignano by Guarini, to know deeply the building with which then the planner would have come to report and that it would have conditioned him in the respect of fundamental parameters as the quotas of stamping and the alignments of façade. To do this it has been planned a study of the project on paper, retrieved on the base of the numerous available monographic publications on the building and from the intersection of information of the plans of the three floors and the two longitudinal sections.

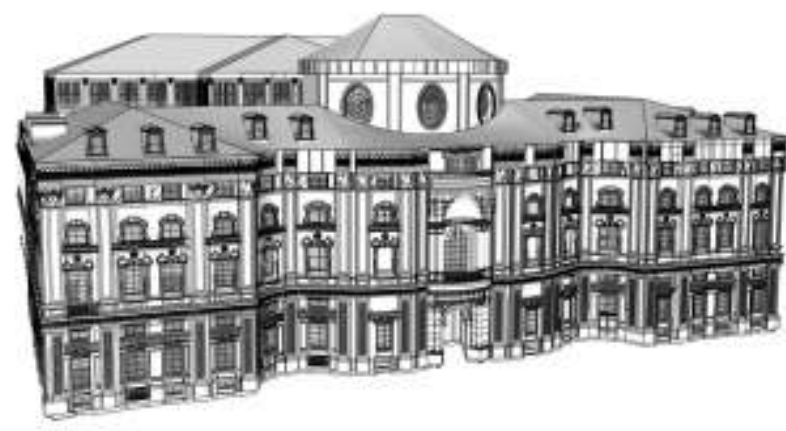

Figure 6. 3D Model of Palazzo Carignano project by Guarino Guarini. F. Giusti, I. Giai Via, A. Quarati, 2014.

\footnotetext{
${ }^{10}$ Sketch-up is an application of computer graphics for the modeling 3D, originally created in 1999 by Brad Schell and Joe Esch and directed to the architectural planning.
}

The model has been enriched with the internal vertical distribution, spiral staircase and big staircases, with a particular study of the turned coverages of the elliptic central body, occupied from Subalpino Parliament room. The decorative apparatus has been realized crossing numerous images of repertoire with the data from the direct observation.

The motivation for which it has been decided to realize the model of the room, that rose in Palazzo Carignano courtyard and that had been commissioned to the ingegner Amedeo Peyron in 1860, it has been the generally little knowledge of this provisional project, but however worthy of note, as excellent representative of the nineteenth-century constructive philosophy. The project foresees in fact a' "bold" wood construction, metal and glass that in its façade took back Romanesque eclectic language, very distant from the lexicon that it will be select from Antonelli for its project. It was therefore deemed meaningful to study the construction in relationship to the contribution of innovation of the constructive techniques of the epoch.

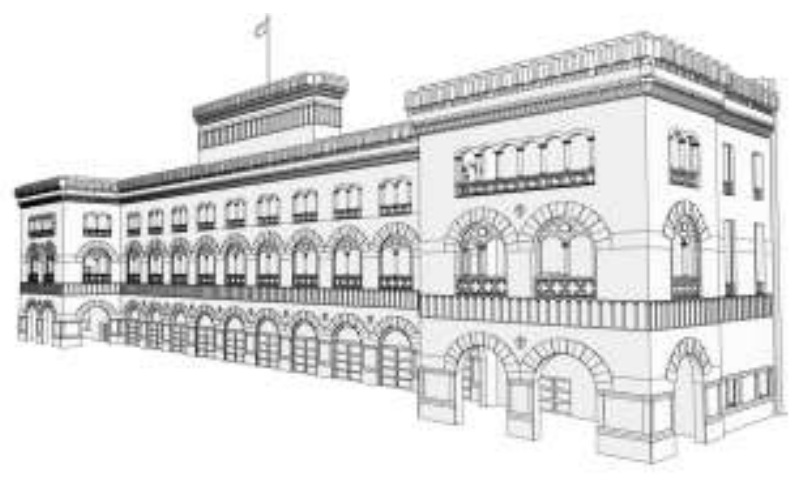

Figure 7. 3D Model of Provisional Parliament room by Amedeo Payron, F. Giusti I. Giai Via, A. Quarati, 2014.

As it regards the realization of the model of the "antonellian" project, it has been decided to depart from the study on paper of the material of file, consistent in a ground floor plan, a longitudinal section, a section of principal elevations and from other bibliographical sources. The doubts and the discrepancies found in the realization of the model are numerous, as numerous are also the incongruities of the project, above all related to the inside vertical distribution and to the accessibility of some inside places as the two libraries or the galleries open to the public. Other inequality between the plan and the section concerns the number of glass spans, side in comparison to the atrium, that in plan result to be seven and not six as in section. To work to the realization of the model has allowed to understand as Antonelli has reported himself with Guarini project, realizing a joint among the sleeves of the two buildings with the hybrid lexicon, with a "guarinian" form in the mural scanning, but with "antonellian" pilasters that are homogeneous to the rest of the decorations. The bond among the two buildings is still strengthened in the inside courtyard with a double portico of Corinthian lexicon, that exactly follows the course of the XVIIth century building and with its rhythmic scanning of columns on two levels it frames the dense decorative apparatus of it. Such project, as it has said, will be discarded by the commission judge of the proclamation even if, comparing the model and the project performed of Domenico 
Ferri and Joseph Bollati, it has been noticed as the same Antonelli had destined great space to the three rooms (general Meeting, Chamber and Senate), in comparison to the project then indeed realized, that introduces just one of it.

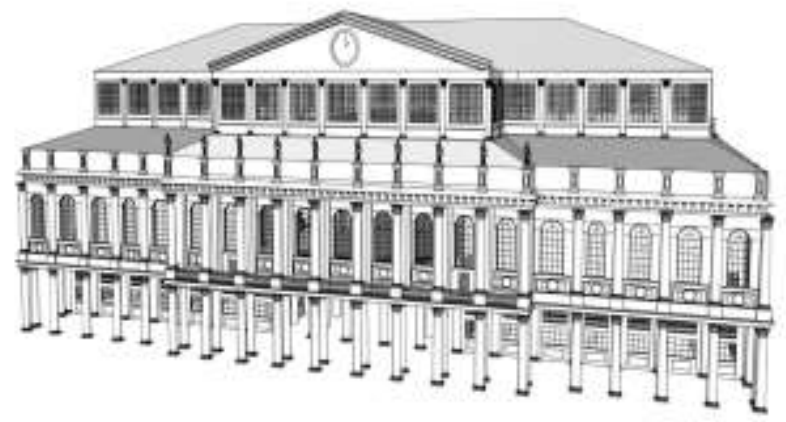

Figure 8. 3D Model of National Parliament project by Alesandro Antonelli. F. Giusti, I. Giai Via, A. Quarati, 2014.

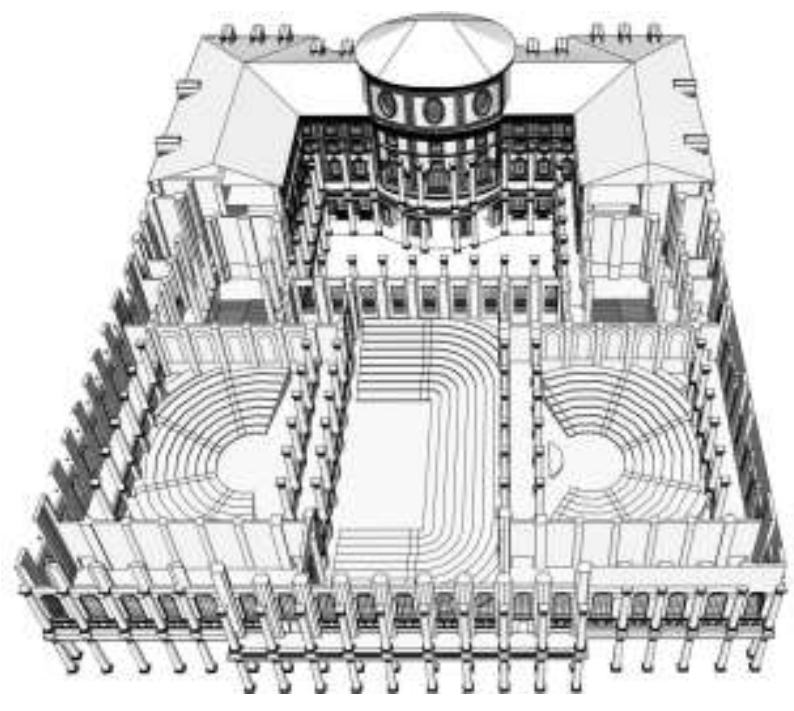

Figure 9. 3D Model of National Parliament project by Alesandro Antonelli and Palazzo Carignano by Guarino Guarini. F. Giusti, I. Giai Via, A. Quarati, 2014.

Lastly, to understand the real impact of the project in its around, a model of the context has been built, selecting the blocks more interested from the intervention and with the porticos that Antonelli wanted to insert in Piazza Carlo Alberto. The language of the project leagues to that of the Collegio delle Province, always of Antonelli's realization, on Piazza Carlo Alberto and via Bogino ${ }^{11}$, with the purpose to guarantee a certain uniformity of the fronts, attempt that will take even more form in the sketch of the porticos for the plaza. For the realization of the elevations of the buildings, documents of the Turin Historical Archive have

\footnotetext{
${ }^{11}$ Alessandro Antonelli in the 1843 signs the project for the new seat of the college for students from the provinces that was planned in the back of Palazzo Carignano stables. The construction start in 1845 , after that the final elaborate was
}

been used. More specifically it's about private building practices related to 1860 , with a critical reading of the documents, in order to distinguish the original aspect of the front from possible interventions attested by the same practices. Normally in red were brought the lines that made reference to the new built while in blue the lines of the existing one. The buildings that lean out on the plazas, that are in prevalence noble buildings not always certified from projects or reliefs and of those of which it has not been possible to retrieve information, have been brought in their real volume with a transparent solid.

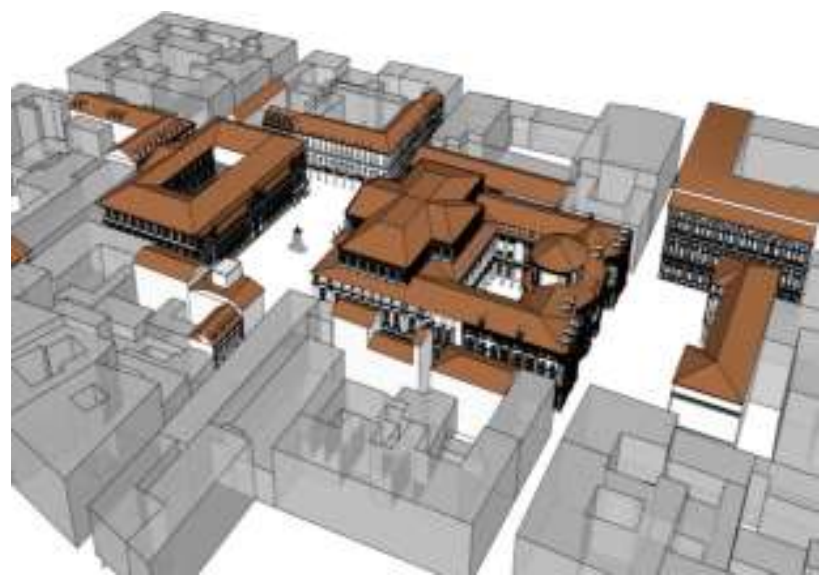

Figure 10. 3D Model of the context around the National Parliament by Alesandro Antonelli and Palazzo Carignano by Guarino Guarini. F. Giusti, I. Giai Via, A. Quarati, 2014.

\section{Conclusions}

The reconstruction of the three-dimensional model, based on a careful and critic study of the iconographic and archiving sources, has allowed to sift Antonelli's project from various points of view, crossing the information inferred by the sketches with the phenomenology of the site, of the architectural and urban context, with the linguistic search and, finally, with the same indications of the proclamation, also in relationship to the definitive choices. Specifically, the cognitive lunge of Antonelli's project allows to realize an indagabile model and therefore able to furnish information on the structure, the functions, the decorative elements, the relationship with the preexistence and the relationships between the building and the city, also in relationship to the urban transformation, putting to comparison the various projects of the contest with the Baroque pre-existence, giving life to a kind of explorable virtual museum. Through the restitution of virtual images it has been possible to optimize the hypothesis, sharpening not only the philosophy of the project, but above all the Antonelli's way to measure himself with such an incisive pre-exsistence in the city as Palazzo Carignano. This because the history of Antonelli's project is just the interaction of more histories: the history of the city development, of the district, of the overall, and of Alessandro Antonelli himself.

drastically reduced, and they continues up to 1851 , however destining it to the centre of financial offices for the state. The building has been demolished after the Secon Wolrd War, to make place to the new national library (ROSSO 1975, p. 170). 


\section{Bibliography}

Cerri, M. G., 1990. Palazzo Carignano: tre secoli di idee, progetti e realizzazioni, Allemandi, Torino.

Comoli Mandracci, V., 1983. Torino. Laterza, Roma.

Dardanello, G., Tamborrino, R., 2008. Guarini, Juvarra, Antonelli, segni e simboli per Torino, Silvana Editoriale, Torino.

Dellapiana, E., 2011. L'ampliamento di Palazzo Carignano a Torino. In: Architettare l'Unità: Architettura e istituzioni nelle città della nuova Italia. F. Mangone, M.G. Tamperi Paparo edizioni, pp 101-111.

Dinucci, R., 1978. Guida di Torino, Edizioni D'Aponte, Torino.

Gabetti, R., 1989. Alessandro Antonelli, Clup, Milano.

Meek, H. A., 1991. Guarino Guarini, Electa, Milano.

Portoghesi, P., 1956. Guarino Guarini 1624-1683, Electa Editrice, Milano.

Rosso, F., 1989. Alessandro Antonelli: 1798-1888, Electa, Milano.

Rosso, F., 1977. Alessandro Antonelli e la mole di Torino, Stampatori , Torino.

Spantigati, C. E. 1988. Un apparato per un regime parlamentare: nascita, fruizione, restauro, in A. Griseri (a cura di), Il Parlamento Subalpino in Palazzo Carignano: strutture $e$ restauro, Torino, pp. 55-58.

Pace, S., 2007. La città eroica. Memoria collettiva e crescita urbana a Torino (1856-1878), in M. Giuffrè, F. Mangone, S. Pace, O. Selvafolta (a cura di), L'architettura della memoria in Italia. Cimiteri, monumenti e città 1750-1939, Milano, pp. 267277.

Portoghesi, P., 1961.Alessandro Antonelli, in Dizionario biografico degli italiani, vol. 3, Istituto dell'Enciclopedia Italiana, Roma. 